\title{
Traditional \& Socio-Cultural Barriers to EFL Learning: A Case Study
}

\author{
Jameel Ahmad ${ }^{1}$ \\ ${ }^{1}$ King Abdulaziz University, KSA \\ Correspondence: Associate Professor of Applied Linguistics, JCC, King Abdulaziz University, PO box 80283, \\ Jeddah 21589, KSA. Tel: 966-553-013-719. E-mail: jahmad1@kau.edu.sa
}

Received: October 12, 2015 Accepted: November 22, 2015 Online Published: November 24, 2015

doi:10.5539/elt.v8n12p191

URL: http://dx.doi.org/10.5539/elt.v8n12p191

\begin{abstract}
This research tends to ascertain several traditional and socio-cultural barriers to English language learning in Saudi Arabia and to explore more ways than before for making teaching and learning more effective. The findings of four quantitative and qualitative surveys conducted in this regard reveal a unique traditional and socio-cultural milieu, which turns the Saudi EFL learners lackadaisical towards English. The belief that prosperity and prestige are blessed by divine force rather than proficiency in English has influenced Saudi parents and Saudi EFL learners since time in memorial. In addition, a laissez-faire attitude to English language teaching in Saudi schools, lack of motivation for English, inadequacy of competitive and learning environment both at home and schools, and the appointment of some unskilled school-teachers were investigated as some of the major barriers to learning English in the Kingdom of Saudi Arabia. A piecemeal reform taken over a period was found ineffective. Therefore, implementation of culturally relevant English curricula, learner-centered instruction, appointment of skilled English teachers and establishment of boarding schools were recommended to address the aforementioned challenges. The findings of the present research are no doubt specific to Saudi EFL context but the traditional and Socio - cultural barriers and the exclusion of local culture in EFL textbooks may have exactly the same impact in many non-native English speaking countries.
\end{abstract}

Keywords: traditional barriers, socio-cultural impact, EFL learning, compatible measures

\section{Introduction}

\subsection{Statement of the Problem}

Traditional and socio-cultural contexts have a huge impact on learners' attitude for learning English worldwide. If socio-cultural environment is competitive and conducive, it shapes positive attitude and nurtures intrinsic motivation for learning English. In other words, learners' positive attitude and their inherent motivation for learning English are conditioned to social environment. This phenomenon is applicable worldwide and Saudi Arabia is no exception to this. Socio-cultural theorists have strong belief that competitive and conducive learning environments inculcate intrinsic motivation in learners from the outset and shape their positive attitude and learning behavior a great deal.

The present study has two goals: to consider why the English language instruction is embraced less enthusiastically and Saudi children are put off English language learning in the Kingdom of Saudi Arabia and to explore some possible strategies for enhancing English language instruction from school to tertiary levels. It is worth noting that there is an irreversible vacuum between Saudi school and Saudi university English curricula. Unlike Saudi schools, Saudi universities have enough qualified \& skilled English teachers, advanced curricula and technology- assisted instructional methodologies, but the language level the Saudi school graduates attained back in school, is beneath the level of Saudi universities. Consequently, their pace of learning English at tertiary level is abysmally disappointing.

The surveys of the present study reveal that Saudi EFL learners' proficiency level is below the expectation owing to multiple traditional and socio-cultural reasons. First and foremost, apart from being the predominant language of Saudi Arabia, Arabic is considered as a linguistic, cultural and religious heritage of Saudi society. Therefore, Saudis give more allegence to Arabic than English. Secondly, English is not widely considered as the only means of survival by all Arabophones, though the inability to communicate in English is considered as an unavoidable barrier in the pursuit of higher education by Saudi educationists. Thirdly, the learners lack intrinsic motivation because their parents are still indifferent towards English. The religious scholars have their own fear and think 
that if English is allowed to grow faster from grass-roots level in Saudi Arabia, it is most likely to deviate Saudi learners from their own linguistic, cultural and religious mores. Nevertheless, it sounds good to reveal that the Saudi government is spending billions on education to upgrade educational standard in general and English curricula in particular in Saudi universities. In addition, Saudi universities are accredited to overseas universities to conform to the global educational benchmark, but the Saudi learners' proficiency in English is still an Achilles heel.

\subsection{Traditional and Socio-Cultural Barriers to English Language Learning}

According to Oxford Dictionary, tradition is a long-established custom or belief that has been passed on from one generation to another and that influences everything including attitude and behavior of the people towards teaching and learning values. The concept of tradition is often considered as the core component of religious belief, culture, knowledge and skills, which do not end with the death of a generation but that each generation transmits to the next what it holds to be precious. It provides a bond between successive generations that practice values, norms, symbols, attitudes and behaviors that are shared throughout history. Tradition is thus a principle of continuity, identity and unity in any culture. While recognizing the role of tradition in human experience of learning and shaping behavior, we also need to recognize Saudis' powerful feeling and their firm adherence to religious values. These religious values refrain some Saudi EFL learners from going crazy for English. In such traditional context, English is never recognized as the only means of livelihood.

Saudi EFL learners in general have pure traditional thinking that obedience or submission to Allah can guarantee respect more than proficiency in English. However, in other non-native English-speaking countries, there is a strong perception that English is an important factor for getting higher social status, honor and respect. In addition, some Saudi EFL learners think differently considering Arabic as a divine language and hence they give more importance to Arabic rather than English. They usually think that English plays a minor rather than major role in bringing about prosperity and honor to one's life. Some Saudis hardly realize that English is an important tool for unprecedented success in educational and occupational careers. However, in modern digitalized age, some major breakthrough is occurring in the attitude of Saudi EFL learners. They have started realizing the importance of English and its significant role in shaping better career, but immense enthusiasm for English is still awaited and long overdue.

According to http://en.wikipedia.org/wiki/ culture is a "complex whole which includes knowledge, belief, art, morals, law, custom, and any other capabilities and habits acquired by man as a member of society." It is also used to denote the complex networks of practices and accumulated knowledge and ideas that are transmitted through social interaction and that exist in specific human groups. Therefore, the word 'Socio- cultural' almost synonymous with tradition, refers to a set of beliefs, customs, practices, behavior and knowledge of a particular group of people, defined by everything from language, religion, cuisine, social habits, music and arts that exist within a population. Socio-cultural barriers to learning English in KSA exist at both home and school. A very few parents monitor their kids' home assignment and as a result, their kids too hardly revise what is taught in the class. In fact, home is the first place where parents are expected to nurture motivation, and to keep the momentum going, they should regularly monitor their kids at home. In addition, all majors are taught and learned in Arabic at the secondary level and English is considered just as a non-existent subject. Consequently, Saudi EFL leaners do not begin to engage with English as a communicative reality but simply as a nondescript subject. They lack aptitude for learning English because neither their parents nor their English teachers of schools enhance their motivation for learning English. The dichotomy between Saudi school and Saudi university curricula, as mentioned earlier, is another big barrier to learning English in Saudi Arabia. The Saudi school graduates are far from the level of language competence the Saudi universities have set for preparatory -year students. A full retrospect of Saudi school is really needed to bring about a holistic educational reform. Their outdated English curriculum, application of old-fashioned instructional methodologies, recruitment policy for English teachers and their insouciant attitude to English lead to somewhat fiasco like situation. On the contrary, Saudi universities have advanced English curriculum, technology-assisted teaching methodologies, competent and skilled English teachers from different nationalities and provision of frequent teacher-training workshops and befitting teaching modules. Such a widening gap and lack of chain-relationship between Saudi schools and Saudi universities deter the goal of learning English, the Saudi universities have set for Saudi learners to achieve at tertiary level.

It is also worth mentioning that the traditional and socio-cultural values of foreign countries as projected in English textbooks are at loggerhead with those of Saudi society. Hence, majority of Saudi EFL learners don't feel motivated to learn English owing to foreign traditions and cultures projected in the English textbooks. This is one of the major traditional barriers to learning English in KSA at tertiary level because Saudi EFL learners 
feel alienated from real life situation as exists in Saudi society. Lack of Saudi local cultures in English textbooks prescribed at tertiary level is somehow disappointing for Saudi EFL learners. According to some linguists, EFL learners learn faster if teaching contents are embedded in local culture. Choice of teacher-centered approach in Saudi school teaching is another pedagogical faux pas which gives EFL learners less opportunity to practice language skills activities and hence impedes effective learning, thereby making them passive recipient in the classroom.

The present study is extremely significant for Saudi educationists and curriculum designers to revisit the entire school and university curricula in order to bring harmony between them and herald a holistic compatible reform. A complete unity and consistency between the KAU schools and universities will make learning and teaching more effective and produce a better outcome. Therefore, it is indispensable to explore pragmatic ways and means and design a curriculum that could address the traditional and cultural barriers to the English language learning in the Kingdom of Saudi Arabia. It seems illogical to design a curriculum and to introduce in Saudi schools and universities, a kind of textbook that doesn't manifest even an iota of local culture and local mindset. Therefore, it needs to investigate systematically what kinds of curriculum and textbooks suit Saudi EFL learners very well and would be more motivating and productive in terms of language acquisition. In this context, the present study will be the harbinger of change in attitude and behavior of Saudi EFL learners to the English language learning.

\subsection{Literature Review}

It is of paramount importance to know what previous researchers think about socio-cultural barriers to learning of English as a foreign language. Lev Semyonovich Vygotsky, (1978) focused on how the circumstances and surroundings of an individual affect his learning behaviors. According to him, people's behaviors, mental \& spiritual development, emotional and physiological beings are all influenced by an age-old tradition and sociocultural environment. It can be deduced that Saudi young learners interact with their predecessors and imbibe the learning aptitude and learning values. According to Hickey, D.T. (2011). "Sociocultural theory maintains that social interaction and cultural institutions, such as schools, classrooms, etc., have important roles to play in an individual's cognitive growth and development. He acknowledged the importance of context and asserted that learners' positive attitude would turn learners more committed and determined in learning English. Gardner and Lambert, (1972), also claimed that 'positive attitude' enhances second language learning, whereas 'negative attitude' does not serve the purpose.

Sivan (1986) proposed that individual goals, their interest for learning and learning values originate from socio-cultural context. Situational interest does influence learners' motivation for learning. According to Weiner (1990), Hidi \& Anderson (1992), Maehr, M.L., \& Pintrich, P.R. (Eds.) (1995), classroom and cultural contexts do increase learners' aptitude for learning. Socio- cultural situation focuses learners' goal of learning, efficacy, and interests. Students' motivation is much more influenced by classroom and sociocultural context. According to McCaslin and Murdock (1991) and McCaslin and Good (1996), motivation begins with the home, classroom and social environment. Optimal learning occurs when the aforesaid environment is conducive and learners adapt to that learning environment. Socio cultural environment has profound implication in building up good habits for learning. According to Tharp and Gallimore (1988), the development of human behavior, motivation and desire for learning emerge out of social interaction. Kim, T. Y. (2006) also attributes individual motivation to socio-cultural context. Ammon (2004) was absolutely right when he claimed that the way learners respond to the target language culture influences their attitude towards the language itself. Lantolf, J., and Thorne, S. (2014) put forth the same view and described language classroom as a collection of various cultural variables.

Another kind of socio-cultural barrier is the inclusion of too much foreign cultures in the English textbooks prescribed in Saudi universities and their imminent impact on Saudi EFL learners. Some linguists have vehemently criticized the teaching of the English textbooks based on target cultures in EFL classrooms. Even European linguists raised strong objections to introducing target language culture in EFL/ ESL classrooms. Linguists have had different views on this issue. Ilter and Ilter, B. G. and Güzeller, C. O. (2005) focused on the positive effect of using target culture in ELT classroom because as per their findings it results in improved social attitude and a positive viewpoint towards the target language community. Correspondingly, Meng -Ching Ho (1998) has related target culture teaching with positive attitudes to learning target language and higher level of motivation. The second group of linguists vehemently criticized the inclusion of target culture in EFL/ ESL classrooms. There is another group who advocates an amalgamation of both local and target language culture and recommends "re-culturing" teaching. Derrington, S. and Kendall, S. (2004) recommend that this amalgamation is the best way to teach those EFL learners . Al-Abed F and Smadi (1996) endorsed the same point and asserted that for an international language like English, cultural connotations are useless, as English has become culturally neutral. Dueñas (2002a) aims to "de-culture" language teaching and dispense with all kinds of 
culture, be it local or target culture. However, introducing foreign culture in language classroom may trigger negative responses as well. Alptekin (1993) opines that teaching target language culture may hinder learners' understanding of language. Nation and Macalister, (2009), discussed the same issue with reference to English language teachers' experiences in Morrocco. They found most of the teachers opposed the teaching of foreign culture in EFL/ ESL classrooms. Fredricks (2007) asserted that learners are more motivated when they learn target language, which is ingrained in their own local culture. Shafaei and Nejati (2008) pointed out that it is imperative to know the learners' culture as it predicts their behavioral patterns related to language learning. It can be deduced that any language teaching practice that excludes learners' culture will be ineffective and may have negative influences on language learning. Culture is an intrinsic part of individuals and keeps shaping their responses. Ariza (2007) also pointed out that abandoning culture is like forgetting one's own self. Therefore, every language teaching policy that aims to be effective has to take the learners' culture into account. Saito, H. and Ebsworth M. (2004) explored that differences in teaching and learning across cultures, can result in cultural misunderstanding.

The opinions of earlier researchers reveal the possibilities of traditional \& socio-cultural barriers to EFL learning and impact of complete exclusion of local culture on EFL learners' attitude to EFL learning. Their views substanciate the hypothesis of the present study. However, the present study is distinct from the views of earlier researchers, because their views regarding the socio-cultural barriers and exclusion of local culture in EFL textbooks are not strongly backed by the experimental findings. Most of the researchers merely rely on the possibility of socio-cultural barriers to EF learning and the huge impact of the exclusion of local culture on EFL learners' motivation and understanding. On the contrary, the present research is based on the insightful quantitative and qualitative surveys conducted on Saudi educationists, journalists, EFL teachers and EFL learners about socio-cultural barriers and Saudi EFL learner's dissatisfaction with the inclusion of too much foreign culture in the English textbooks presecribed in Saudi universities. Moreover, unlike the general opinion of earlier researchers, the present research is specific to Saudi EFL learners: starting from the insightful findings of Saudi specific context to generalized context. In other words, the aforesaid traditional and socio -cultural barriers and the exclusion of local culture in EFL textbooks may have the same impact in other non-native English speaking countries as in Saudi Arabia. The present research is built around the following important hypothesis:

\subsection{Hypothesis}

1. The belief that English is a non-divine language, prestige \& prosperity are blessed by divine force rather than proficiency in English somewhat affect Saudi learners' intrinsic motivation for learning English. 2. The casual attitude of some Saudi parents and their lack of higher academic ambition for their children unconsciously affect the intrinsic motivation of their children for learning English. 3. The belief that domination of English in school curricula will cause irreversible loss of religious \& linguistic identities, somehow, affects Saudi school English curricula. 4. Lack of parents' habit to assist learners' home assignments \& lack of learners' habit for revision affect learners' pace of learning English. 5. Application of teacher-centered rather than learner-centered approach in EFL classes at schools is uninspiring for Saudi EFL/ESL learners. 6. English teachers' preference to speak Arabic consistently in EFL classes makes Saudi students relaxed and demotivated for English. 7. Inclusion of too much foreign culture in English textbooks at tertiary level also affects Saudi learners' motivation for learning English.

\section{Materials and Methods}

The present research is based on the primary data as well as secondary data. The primary data were collected through statements/ questionnaires and secondary data from published sources

\subsection{Primary Data}

The research team has collected first-hand information from around one thousand respondents including male students, parents, male journalists and male teachers of government schools, colleges and universities of Saudi Arabia. Owing to traditional hindrance, it was rather difficult to elicit the responses of female counterparts. Therefore, the present study relies merely on male participants. The primary data have been collected by administering structured statements from the respondents randomly selected from three major cities of Saudi Arabia, i.e., Jeddah, Makkah and Riyadh.

\section{2 Secondary Data}

Secondary data refers to the already collected and published information about traditional and socio-cultural barriers to EFL learning. In the present research, the intensive and extensive information regarding the said topic have been collected from the following authentic published sources: 1. Online resources include research papers 
on socio-cultural barriers published online. 2. Articles on socio-cultural barriers published in Saudi Daily English newspapers.3. Strategic plans of schools colleges and universities for last five years. 4. Different magazines and research journals regarding EFL learning in Saudi Arabia. The comprehensive details of research methodology of the proposed research based on primary and secondary are as follows:

\subsection{Data Collection Methods}

The methodology of the present research embarks on primary data as well as secondary data. Quantitative and qualitative methods were used to collect the primary data. Quantitative approach was used to elicit the overwhelming response of Saudi male EFL/ ESL teachers in fairly large numbers on traditional barriers and socio-cultural impact in learning English in KSA. Quantitative data have been used to collect overwhelming responses of a large number of respondents and determine their probability value which is statistically analyzable. Quantitative data are considered objective and subjected to statistical procedures that can give definitive or nearly definitive result, in terms of responses to different statements.

In the present study, respondents were offered a choice of five pre-coded responses. Likert Scale's five point scale was used to allow the individuals to express how much they agree or disagree with a particular statement. Likert's five-point scale, based of "Strongly agree / agree / don't know / disagree / strongly disagree" was used to explore hard facts about the real traditional barriers and socio-cultural impact in English language learning in KSA, so that reliable statistical findings could be drawn and compatible remedial measures could be applied. Respondents were offered a set of statements to tick from predefined selections such as "Strongly agree / agree / don't know / disagree / strongly disagree". In order to ascertain the real barriers to English language learning, four surveys were conducted on Saudi male students, parents, Saudi male journalists and EFL / ESL Saudi School and university male teachers working in Saudi Arabia. The sample composed of one thousand male teachers of English from different nationalities, mostly from KSA, ranging in age from 30 to 50 years.

There is no doubt that quantitative approach (questionnaires/ statements) is one of the most important tools for data collection in experimental research because it is useful to elicit overwhelming response and establish opinions (Cohen, Manion, \& Morrison, 2007). However, according to number of research studies, self-reporting questionnaires or statements are not totally reliable and usually depict an incomplete picture of the situation (Davidman, 1981). Similarly, Pintrich and Schunk (2002, p. 11) also recognized the value of qualitative research 'for raising new questions and new slants on old questions'. For these reasons, individual interviews, focused group and informal journalistic conversations were conducted in the present study to gain in-depth understanding about traditional \& socio-cultural to EFL learning and their compatible reform. The interviews were conducted so as to get some valid reasons for Saudi learners' lack of motivation for learning English and viable solution. Therefore, both quantitative and qualitative approaches were used to produce more logical led findings.

\subsection{Data Sampling and Analysis}

Data analysis was carried out both quantitatively and qualitatively. Figures and tables were used to validate exact statistical findings. Percentages were utilized to show the participants' overwhelming response on traditional barriers and socio-cultural impact in learning English in Saudi Arabia. One thousand respondents including Saudi EFL/ ESL students, teachers, some educated Saudi parents and Saudi journalists participated in the present research and revealed their experiences forthrightly. The respondents were asked to check strongly agree / agree / do not know / disagree / strongly disagree on four statements pertinent to traditional barriers in learning English. These four statements were designed to elicit what degree: strongly positive, moderate, or negative, the participants agree or disagree on the said statements. The sample of statements related traditional barriers is given below:

Sample 1. Statements on traditional barriers to learning English

1. The belief that Arabic is a divine language \& English is non-divine, hence unworthy of consideration, affects Saudi EFL/ESL learners' motivation for learning English.

2. The belief that prestige \& prosperity are blessed by divine forces rather that competence in English somewhat affects Saudi learners' intrinsic motivation for learning English.

3. Saudi parents' lack of higher academic ambition for their children inculcates no intrinsic motivation in them for English.

4. The belief that domination of English in school curricula will cause loss of religious \& linguistic identities prevents Saudi learners' desire for learning English. 
In the second survey, four statements pertinent to socio-cultural barriers in learning English in KSA were handed over to the respondents to check strongly agree / agree / don't know / disagree / strongly disagree. Saudi EFL/ ESL/ teachers from Saudi schools and universities, Saudi journalists and Saudi EFL learners from Saudi colleges and universities participated in this survey and gave their insightful responses. (Immense thanks to them). The sample of statements related socio-cultural barriers to English language learning is given below:

Sample 2. Statements on socio-cultural barriers to learning English

1. The Unfavorable attitude of some parents towards English demotivates their children for learning English in KSA.

2. Lack of parents' realization that deficiency in English will affect learners' professional careers is a barrier to KSA learners' interest for English.

3. Lack of parents' habit to assist learners' home assignments \& lack of learners' habit for revision affect learners' pace of learning English.

The third survey was conducted to explore the socio-cultural barriers to English language learning at school. The major respondents of this survey were the EFL / ESL teachers and students who graduated from Saudi government schools. The sample of statements related socio-cultural barriers to English language learning at government schools is given below:

Sample 3. Statements on Socio-cultural barriers at government schools

1. Lack of trained teachers or inadequate teaching methodology in schools affect Saudi learners' pace of learning English.

2. Application of teacher-centered rather than learners centered approach in English classes at schools is uninspiring for Saudi EFL/ESL learners.

3. English teachers' leniency and their preference to speak Arabic regularly in English classes make Saudi students relaxed and demotivated for English.

4. Inclusion of too much foreign culture in English textbooks also affects Saudi learners' motivation for learning English.

The fourth survey was conducted to explore KSA EFL/ ESL/ learners' and their parents' motivation and attitude towards EFL learning. The major respondents were the graduates from government schools, pursuing higher studies in the universities. They will respond Yes or No. The sample of statements is given below:

Sample 4. Motivation and attitude towards English

1. Do you revise \& study English at home every day?

2. Does your father assist and motivate you to learn English at home?

3. Did your teacher often use to teach English in Arabic in your primary and secondary schools?

4. Did your teachers encourage you to speak English in primary and secondary school?

5. Did your teacher often use to teach English in Arabic in your primary and secondary schools?

\section{Results/ Discussion}

The findings of the first survey in table.1 are based on the statements of traditional barriers to learning English as a foreign language. The research findings reveal that traditional belief is responsible, to greater extent, for Saudi learners' impervious attitude to English. In fact, religious belief acts as a strong force in Saudi society and does have considerable influence over Saudi EFL learners' motivation and their attitude towards English. 
Table 1. Results on traditional barriers to learning English

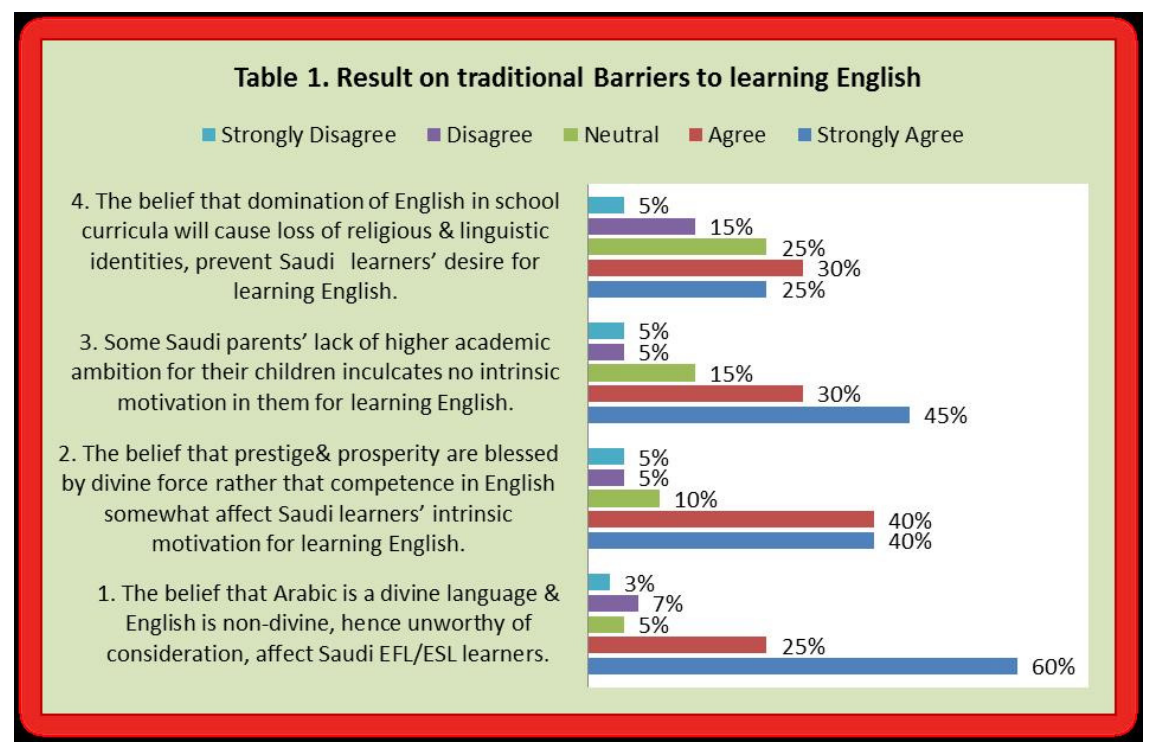

Saudi Parents, journalist, students, and Saudi government school-teachers and Saudi university-teachers participated in this survey. $80 \%$ respondents agreed that the belief 'English is considered as non-divine language' somehow affects learners' motivation for learning English'.Therefore, the result of quantitative survey shows a strong agreement with the said statement. The qualitative approach is significant in exploring "why and how" which encapsulates the wide spectrum of the situation. The majority of the respondents argued that Saudis consider English as non-divine that lays far-reaching impact on their attitude towards English. Hence, some Saudis hardly motivate their children to learn English at childhood. The findings of the qualitative survey also reveal that a handful of educated Saudis realizes the global importance of English in academic, professional and business activities. Therefore, for them to consider English as a divine or a non-divine language does not arise. What matters most to them is to consider English as an important means for higher studies and a link language for running oversease business-activities. One respondent who is a notable journalist opined, "English is a non-divine language but it is used for divine purposes such as to preach Islamic values to non-native speakers of Arabic". Another senior journalist pointed out that "forty or fifty years ago Saudis had an inherent disliking for English, because Arabic was the only language they were spiritually adhered to. However, in the modern scientific and digital age, things are changing a great deal, and even some uneducated Saudis have started realizing the importance of English in different facets of life".

As per the second statement, $80 \%$ Saudis strongly supported the belief that prestige and prosperity are blessed by divine force rather than competence in English and this very belief consciously or unconsciously does influence Saudi EFL learners' attitude and motivation a great deal. Only 10\% disagreed and $10 \%$ remained neutral. The qualitative survey in this regard reveals that the majority of Saudis firmly believe in divine force that is solely responsible for one's prestige and prosperity rather than the competence and proficiency in English. However, the logical response of educated Saudis is worth noting. One of the educated respondents opined, "There is no doubt prestige and prosperity are blessed by divine force, but English does facilitate global business activities". Another educated Saudi said global prestige and prosperity are earned via English because it has become a link language worldwide. The interviews with different educated Saudis explain the changing attitude of the people. Their adherence to religion is beyond doubt, but their realization about the importance of English in business is also genuine and pragmatic.

The findings of third statement are really worth mentioning. The statement that Some Saudi parents' lack of higher academic ambition for their children inculcates no intrinsic motivation in them for learning English". In response to this statement, $85 \%$ respondents agreed and only $10 \%$ respondents were found disagreeing. Individual and group interviews manifest that the uneducated Saudis are unable to set higher ambition for their children, because they don't have good account of knowledge about higher academic and professional courses where English is crucial for getting excellence. Therefore, lack of parents' higher ambition for their children is responsible for making their children unenthusiastic for learning English. On the contrary, educated parents send their children abroad for higher studies and focus on English language learning because they know well that 
competence in English plays a very vital role in building sound career.

In response to the fourth statement, as per the quantitative survey, 55\% Saudis agreed, 20\% disagreed and 25\% remained neutral. Some participants argued that domination of English in school curricula would cause loss of religious \& linguistic identities. This is why in all Saudi government schools; the medium of instruction is Arabic up to higher secondary level. Some educated Saudis from religious background have a phobia about introducing English from LKG, or introducing English as a medium of instruction in Saudi government schools. Many participants in group-interviews considered this phobia quite genuine. Some participants argued that though it is not advisable to introduce English as medium of instruction in government schools, however it could be introduced as a foreign language right from LKG onwards.

The findings of second survey in Table 2 provide enough clues about socio-cultural barriers to learning of English as a foreign language. Social environment lays its huge impact on learners' intrinsic motivation for learning of English as a foreign language. Parents' attitude and how they perceive the importance of English in current social situation also influence their children's learning behavior.

Table 2. Results on socio-cultural barriers to learning English

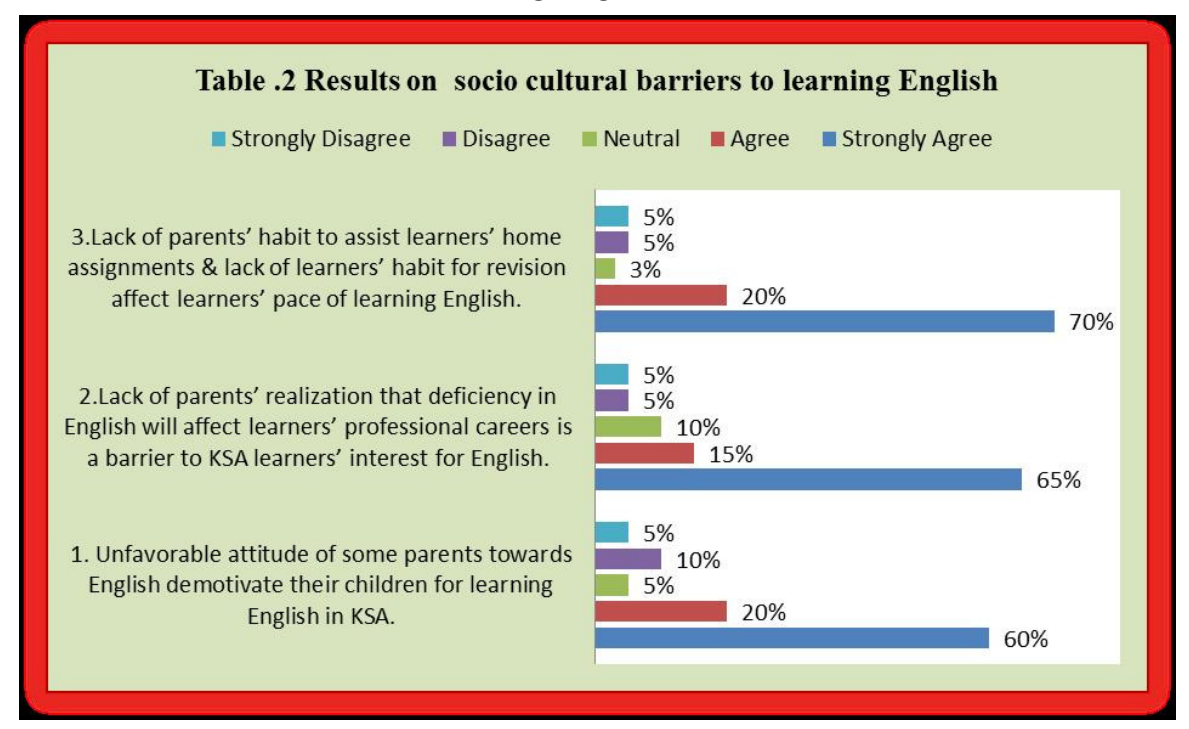

The findings of the second survey in Table 2 are alarming. In response to the first statement, $80 \%$ respondents supported that unfavorable attitude of parents towards English demotivate their children for learning English. The qualitative survey on the first statement suggests that the overwhelming majority of respondents accepted that Saudi parents, neither motivate their children to learn English nor assist their children's English related home assignment because they are too busy to support their children to learn English systematically. The findings of the second survey in Table 2 are worth pondering. In response to the first statement, $80 \%$ respondents supported that unfavorable attitude of parents towards English demotivate their children for learning English.

The qualitative survey on the first statement in Table 2 suggests that the overwhelming majority of respondents accepted that Saudi parents, neither motivate their children to learn English nor assist their children's English related home assignment because they are too busy to support their children to learn English systematically. Consequently, Saudi children are unable to build regular habits to revise what is taught in the class and to study at home in an organized manner. In response to the second statement, $80 \%$ respondents agreed that parents' non-realization of the adverse effect of their children's deficiency in English is responsible for shaping negative attitude towards English. It emerged out of the group discussion that the problem lies in the attitude of uneducated parents who are incapable of realizing the importance of English in higher education. Parents' inability to assist their children's efforts to learn English at home has adversely affected learners' pace of learning. That is why $90 \%$ respondents in response to the third statement, agreed that learners make no efforts to expedite their learning process at home due to lack of support from their parents. The overwhelming majority of the respondents in quantitative survey proved that pace of learning English will be far better if learners are regularly tutored at home either by their parents or by competent tutors. The findings of qualitative survey on this statement give a clear picture and unfold innumerable benefits of revision at home. One senior professor 
argued that revision is prerequisite to increase memory process. It creates in-depth understanding of the issues discussed in the class and reinforces what is taught / learned in the class. Unfortunately, the culture for both pre-study and post study are lacking in Saudi society that puts motivation and learning at a low pedestal.

Table 3. Results on socio-cultural barriers to learning English at school level

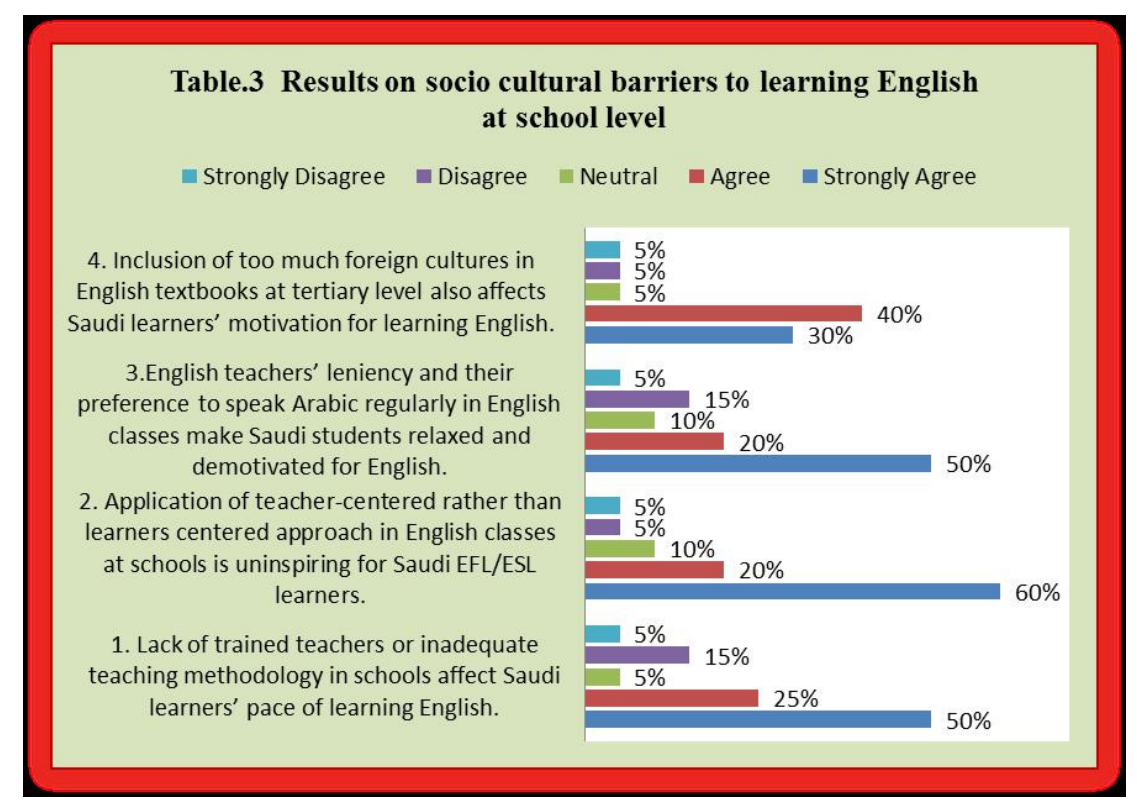

The third survey in Table.3 is an exploration of the basic barriers Saudi learners are confronted with, while learning English at government schools. As per the quantitative survey, $75 \%$ respondents agreed that the lack of trained teachers and inadequate English curricula are some of the major barriers to learning English at schools. Only $25 \%$ respondents expressed different opinion on the said statement. The observations of the qualitative survey are alarming. Almost all the participants raised similar voice that teachers of English are directly recruited from schools soon after baccalaureate degrees. Teaching English is one of the optional papers for the students who are pursuing graduation in the Department of European Languages and Literature at Saudi universities. The students who opt for teaching English paper in graduation are, no doubt, aware of up-to-date teaching methodologies to some extent. Therefore, they can teach better than those who do not opt for teaching English paper in graduation.

In response to the second statement of the third survey, $80 \%$ respondents supported the idea that teacher-centered approach is an uninspiring for EFL learners. Only $20 \%$ respondents were having no objection with teacher-centered approach. The qualitative survey on this statement has explored some logical and convincing findings. Around $80 \%$ respondents argued that the application of learner-centered approach instead of teacher-centered approach in Saudi schools would increase learners' performance in English at school. Learnercentered approach is now recognized as the most effective teaching approach across the globe because it puts students at the heart of the learning process.

The third statement is based on the attitude of English teachers of Saudi government schools. With regard to the third statement, only $20 \%$ respondents disagreed, $10 \%$ remained neutral, but $70 \%$ respondents agreed that teachers' leniency and their preference to speak Arabic regularly in English classes make Saudi students relaxed and demotivated for English. Therefore, Saudi students vehemently criticize school teachers when they join universities and see the benefits of English medium instruction and the far-reaching impact of learner-centered approach in their performance.

The findings of fourth statements are noteworthy because they reflect an insightful observation and experience of the participants. According to the statistical finding of quantitative survey, $70 \%$ respondents supported the statement that inclusion of too much foreign culture in English textbooks at tertiary level also affects Saudi learners' motivation for learning English. In addition, the outcomes of qualitative survey transpire learners' dissatisfaction with inclusion of foreign cultures in English textbooks, because the teaching contents become out 
of their spectrum of interest. According to some of the participants, Saudi cultural values are at wide variance with western cultural values. The manifestation of some western cinematic values in English textbooks prescribed in Saudi universities is the real cause of dissatisfaction for some Saudi EFL learners. Some of the Saudi learners who are from purely religious backgrounds feel major threat to their religio-cultural worldviews. In addition, it was found that English textbooks written by Western writers do not conform either to the level of Saudi EFL beginner-learners or to the ESP learners. Saudi learners of English are unable to cope up with the level of English used in these textbooks. Therefore, there is a need to write English textbooks at all levels that cater to the contexts, needs and levels of Saudi learners. In order for pedagogy to be relevant, the teaching materials should be in conformity with the level of Saudi EFL learners.

Table 4. Motivation \& attitude towards learning English

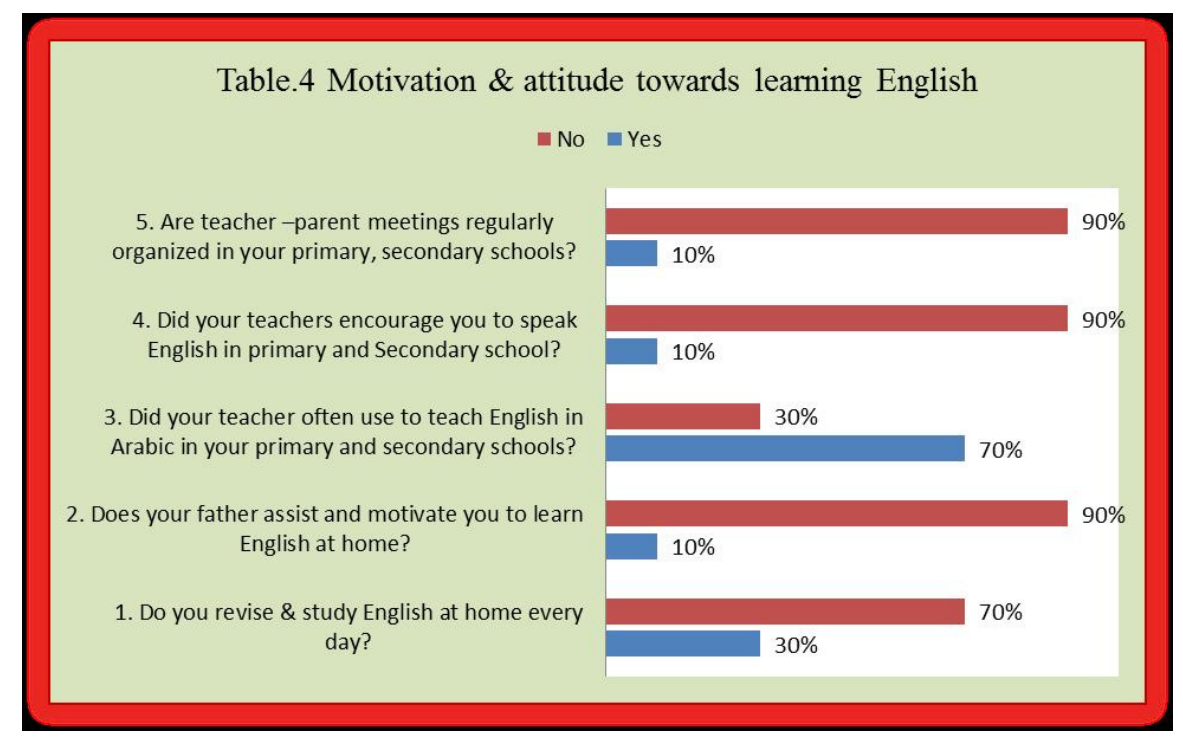

The findings of fourth Survey in Table 4 manifest learning environment and Saudi parents / learners' attitude towards English. In response to the first question, $80 \%$ students said that they never open books and revise what is taught in the classrooms. Only $20 \%$ students said they revise but just for half an hour every day. In response to the second question, 90\% students reported that their parents never motivate them to learn English at home. Only $10 \%$ students reported that their parents motivate them to learn English. It emerged from the qualitative survey that there is no culture of revision at home. Learning English is not learners' priority at all in Saudi Arabia. However, some educated Saudi parents motivate their children to learn English to boost educational and professional careers. In response to the third question, $70 \%$ students reported that their teachers of English at school level used to teach English in Arabic medium frequently. 90\% students said that they had never been encouraged to speak English at schools. To speak English at schools was considered as taboo at school. During discussion with Saudi students, it was explored that they were allocated only 45-minute class each day for learning English at school. In addition, the instructional method was traditionally teacher-centered rather than learner-centered. In response to the fifth question, 90\% students reported that parent- teacher meetings were not regularly organized in schools. It means there is no mechanism in schools to inform parents of their children's performance in summative assessment.

\section{Compatible Remedial Measures}

In the light of quantitative and qualitative surveys conducted in the present research, some possible remedial measures were explored with a view to improving Saudi learners' motivation for learning of English as a foreign language. Some invaluable and compatible panaceas in this regard that emerged out of group discussion and individual interviews are given below:

Regular parents-teacher meeting must take place in Saudi government schools so that uneducated parents could be motivated to hire special teachers who could assist their children's home assignment and improve their communication skills. Parents and teachers, both should work out at how to build learning habits and motivate Saudi EFL learners to study at home on a regular basis. If parents and teachers succeed in building up habits for 
self-study, learners will learn English faster.

Many respondents recommended that English language learning in the kingdom should be introduced in the first class in the primary schools if not from kindergartens. It should be taught by qualified, skilled and efficient teachers of English. There is a need to organize specific teacher-training workshops in Saudi schools and apply adequate teaching methodologies to raise the standard of English in Saudi schools, colleges and universities.

Establishing boarding school is a better panacea to obliterate laissez-faire attitude towards learning English in Saudi Arabia. Researches show that the residential campus environment ensures a conductive learning environment because campus-students are immersed in an educational world where learning is central to all activities. In addition, students are forced to follow discipline and get ample chance to improve their language skills by frequently interacting with peers and groups.

Saudi institutions need to set a specific goal for learning English from nursery to tertiary levels. Whatever proficiency level in English the Saudi students are supposed to acquire at schools and colleges must be predetermined. Language learning will be at best when the syllabus is broken down into manageable goals that are achievable over a specified time-frame. Besides, Saudi schools, colleges and the universities must conduct annual surveys to investigate how much of the specified goals for learning English has been achieved so that remedial measures could be applied accordingly.

There is a need to reinvent English syllabus and bridge the gap between Saudi school and Saudi college English curricula. One of the English professors of KAU has consistently found that some students come into Level 1 in Module 1at tertiary level is unable to read and write enough to deal with a "Beginning" level course book. If the Saudi school system, after so many years of English language teaching, cannot even produce students who can read and write enough and to understand a "Beginning" level course book, there is really a serious problem. Such a poor proficiency level of school graduates creates a big gap between the school and college English curricula.

Technology assisted language learning, hailed worldwide can be implemented as a profound pedagogical tool in Saudi schools, colleges and universities. The use of electronic gadgets for English language learning will be a great source of motivation for Saudi EFL learners. Electronic gadgets have grown by leaps and bounds and have permeated into all facets of human life. Saudi EFL learners should be trained to make the best use of electronic devices to learn English effectively. Mobiles with Internet connectivity have an edge over computers and laptops by virtue of their small size and being portable. If ELT materials are downloaded on Internet mobiles it can create a better environment and motivation for English language learning, because Saudi EFL learners can use them in spare moments anywhere.

\section{Conclusions}

The quantitative and qualitative surveys conducted in the present research confirm that traditional and socio-cultural values set priorities and shape the attitude of the society as a whole either in favor or against education in general and learning of English in particular. The environment for learning English from homes to schools would be far more conducive if traditional and Socio-cultural values nurture favorable attitude towards learning English. In case of lackadaisical attitude towards English, the motivation level of learners will be abysmally poor. The assumption that English is the only means of prestige and prosperity, in some countries where English is enjoying the status of more than a second language, learning of English is put at a high pedestal. In the case of Saudi Arabia, prestige and prosperity are perceived more as a divine blessing rather than the intervention of a worldly language. This inherent traditional belief unconsciously refrains people from being too enthusiastic for English language learning. The findings of the present research also reveal that there is brewing fear among Saudi scholars that domination of English in government school curricula might put linguistic and Islamic values at stake. However, EFL/ ESL learners of many non-English speaking countries, except Saudi Arabia, now consider English as a potent means to grow from rags to riches. Hence, they are quite enthusiastic and have nurtured enough intrinsic motivation to learn English with their own cultural milieu. On the contrary, Saudi learners' feel- relaxed attitude towards learning in general is a big barrier to learning of English in Saudi Arabia. Another important investigation of the present research is the lack of unification between school and college curricula. The goal and outcome of learning English in government schools are not so well defined, hence not so well achieved. There is a need to close the attainment gap between Saudi schools and Saudi colleges. The English curriculum of government schools must be aimed at producing such graduates who are able to read, understand, speak and write English with ease while pursuing their higher studies in Saudi universities. In addition, English textbooks need to be written with the Saudi context incorporating, 70\% Saudi cultures and $30 \%$ global cultures in order to boost Saudi EFL learners' motivation for learning English. Such 
kinds of English textbooks will lay far-reaching impact on Saudi EFL learners' motivation for English language learning in Saudi Arabia.

It was also explored that using the teacher-centered approach in English classes of government schools is one of the major barriers to learning English. Learners are given least opportunities to immerse in learning process and reflect their own learning experience. On the contrary, learner-centered approach makes learners realize their full potential embarking on the self- paced learning process rather than to be considered just as empty vessel or passive receptor blindly relying on teachers as full authority. The Learners centered approach is time tested and it is purely a participatory approach, where students are actively engaged in the whole learning process. The ethos behind learners centered approach is to inculcate in learners an intrinsic motivation for learning, with the emphasis being on cooperation, rather than competition, between students. Therefore, Saudi school teachers of English must be given intensive training about how to use learner-centered approach in English classes to make Saudi EFL learners actively engaged in the whole learning process through peer-to-peer or group activities. The entire focus of teaching should not be just on what is taught in the class, but on how effective learning is promoted.

\section{Limitations}

The present study has certain limitations with regard to the statistical surveys. The surveys of this study were conducted only on Saudi male EFL / ESL, students, teachers, university professor, parents and Saudi journalists. This research will build a solid foundation for other researchers to do intensive research on unavoidable barriers that Saudi female students are currently confronted with while learning English in Saudi Arabia. It is possible that Saudi female students are faced with entirely different problems while learning English at home and Saudi schools and colleges. Based on this research, other researchers can elicit the views and genuine arguments of female students, teachers, university female professors and female journalists to obtain the more pragmatic recommendation.

\section{Acknoledgements}

This project was funded by the Deanship of Scientific Research (DSR), King Abdulaziz University, Jeddah, under grant no. 026/156/1434. The author, therefore, acknowledge with thanks DSR technical and financial support.The author is indebted to all JCC fraternity: dean, Dr. Ahmed Alabdulwahab and GRC chairman, Dr. Turki Alsolami. The author is also thankful to KAU students, their parents and Saudi journalists for participating in quantitative and qualitatitve surveys conducted in this study. Special thanks are owed to Dr. Islam Al-Murabit, Dr. Ahmad Al Ghamidi and Mr. Abu Bakar.

\section{References}

Abed, F., \& Smadi, O. (1996). Spread of English and westernization in Saudi Arabia. World Englishes, 15(3), 307-315. http://dx.doi.org/10.1111/j.1467-971X.1996.tb00117.x

Ammon, U. (2004). Sociolinguistics: An international handbook of the science of language and society (2nd ed.).

Alptekin, C. (1993). Target language culture in EFL material. ELT Journal, 47(2), 136-143. http://dx.doi.org/10.1093/elt/47.2.136

Ariza, D. (2007). Culture in the EFL classroom in Universidad de la Selle: An innovation project. Actual ideas, Padagogicas, 09-17.

Cohen, L., Manion, L., \& Morrison, K. (2007). Research methods in education. London: Routledge.

Davidman. (1981). Learning style: The myth, the panacea, the wisdom. Phi Delta Kappan, 62(9), 641-645.

Derrington, S., \& Kendall, S. (2004). Gypsy Traveller Students in Secondary Schools. Sterling, VA: Trentham Books [Electronic version].

Dueñas, M. (2002). Acquiring cultural knowledge through content-enriched instruction. Babylonia, 3, 58-62.

Fredricks, L. (2007). A rationale for critical pedagogy in EFL: The case of Tajikistan. The Reading Matrix, 7(2), 22-28.

Gardner, R., \& Lambert, W. (1972). Attitudes and motivation in second language learning. Rowley, MA: Newbury House.

Hickey, D. T. (2011). Participation by design: Improving individual motivation by looking beyond it In D. M. McInerney, R. A. Walker, \& G. Liem (Eds.), Sociocultural theories of learning and motivation: Looking back, looking forward (pp. 137-161). Charlotte, NC: Information Age Publishing Inc. 
Hidi, S., \& Anderson, R. (1992). Situational interest and its impact on reading and expository writing. In K. A. Renninger, S. Hidi, \& A. Krapp (Eds.). The role of interest in earning and development (pp. 215-238). Hillsdale, NJ: Erlbaum.

Ho, Meng-Ching (1998). Culture studies and motivation in foreign and second languagelearning in Taiwan. Language, Culture and Curriculum, 11(2), 165-182. http://dx.doi.org/10.1080/07908319808666548

Ilter, B. G., \& Güzeller, C. O. (2005). Cultural problems of Turkish students while learning English as a foreign language.

Kim, T. Y. (2006). L2 learning motivation from a sociocultural theory perspective: Theory, concepts, and empirical evidence. English Teaching, 61(4), 51-78.

Lantolf, J., \& Thorne, S. (2014). Sociocultural theory and the genesis of second language development. Oxford: Oxford University Press.

MaCaslin, M., \& Good, T. (1996). The informal curriculum. In D. Berliner, \& R. Calfee (Eds.), The handbooks of educational psychology (pp. 622-673). New York, NY: MacMillan.

MaCaslin, M., \& Murdock, T. B. (1991). The emergent interaction of home and school in the development of adaptive learning. In M. L. Marhr \& P. Pintrich (Eds.), Advances in motivation and achievement (pp. 213-259). Greenwich, CT: JAI Press.

Maehr, M. L., \& Pintrich, P. R. (Eds.) (1995). Advances in motivation and achievement: Culture, motivation, and achievement. Greenwich, CT: JAI Press.

Nation, I. S. P., \& Macalister, J. (2009). Language curriculum design. Taylor and Francis. European Journal of Social Sciences, 23(4), 613.

Pintrich, P. R., \& Schunk, D. H. (2002). Motivation in Education: Theory, Research and Applications.

Shafaei, A., \& Nejati, M. (2008). Global practices of language teaching: Proceedings of the 2008 international online language conference. Universal-Publishers.

Saito, H., \& Ebsworth, M. (2004). Seeing English language teaching and learning through the eyes of Japanese EFL and ESL students. Foreign Language Annals, 37(1), 111-122. http://dx.doi.org/10.1111/j.1944-9720.2004.tb02178.x

Sivan, E. (1986). Motivation in social constructivist theory. Educational Psychologist, 21(3/4), 290-233. http://dx.doi.org/10.1207/s15326985ep2103_4

Tharp, R. G., \& Gallimore, R. (1988). Rousing minds to life: Teaching, learning, and schooling in social context. Cambridge, UK: Cambridge University Press.

Vygotsky, L. S. (1978). Mind in society: The development of higher psychological processes. Cambridge, MA: Harvard University Press.

Weiner, B. (1990). The history of motivation research in education. Journal of Educational Psychology, 82(4), 616-622. http://dx.doi.org/10.1037/0022-0663.82.4.616 


\section{APPENDICES}

Please choose a response to the statements below which describe traditional \& Socio-cultural barriers in EFL learning

\begin{tabular}{|c|c|c|c|c|c|c|}
\hline No & Statements & $\begin{array}{l}\text { Strongly } \\
\text { Agree }\end{array}$ & Agree & Neutral & Disagree & $\begin{array}{l}\text { Strongly } \\
\text { Disagree }\end{array}$ \\
\hline & Socio -Cultural Barriers at School Level & & & & & \\
\hline 1 & $\begin{array}{l}\text { Less priority on English in KSA schools is a big } \\
\text { hindrance in learning. }\end{array}$ & & & & & \\
\hline 2 & $\begin{array}{l}\text { Medium of instruction is Arabic in KSA schools. It } \\
\text { discourages learning English. }\end{array}$ & & & & & \\
\hline 3 & $\begin{array}{l}\text { School environment in general isn't conducive for } \\
\text { learning English }\end{array}$ & & & & & \\
\hline 4 & $\begin{array}{l}\text { Lack of strict rule for learning English in KSA } \\
\text { schools is one of the hindrance in learning English }\end{array}$ & & & & & \\
\hline 5 & $\begin{array}{l}\text { School teachers' leniency while evaluating students' } \\
\text { answer sheet in the exam make students relaxed }\end{array}$ & & & & & \\
\hline 6 & $\begin{array}{l}\text { Lack of proficiency and competence of school } \\
\text { teachers in English is responsible for learners' } \\
\text { unsatisfactory performance in English. }\end{array}$ & & & & & \\
\hline 7 & $\begin{array}{l}\text { Only multiple choice questions in exam prevent the } \\
\text { students from hard work in English }\end{array}$ & & & & & \\
\hline 8 & $\begin{array}{l}\text { Casual attitude of KSA school teachers towards } \\
\text { English causes hindrance in learning English later in } \\
\text { their career. }\end{array}$ & & & & & \\
\hline 9 & $\begin{array}{l}\text { The KSA students aren't well encouraged for learning } \\
\text { English at schools. }\end{array}$ & & & & & \\
\hline 10 & $\begin{array}{l}\text { Lack of counseling in schools about the importance } \\
\text { of English in higher education and in professional } \\
\text { career. }\end{array}$ & & & & & \\
\hline 11 & $\begin{array}{l}\text { Lack of pressure for learning English at schools } \\
\text { makes KSA learners relaxed. }\end{array}$ & & & & & \\
\hline 12 & $\begin{array}{l}\text { Lack of competitive environment for learning English } \\
\text { in schools is one of the barriers in learning English }\end{array}$ & & & & & \\
\hline 13 & $\begin{array}{l}\text { Lack of holistic and sound school curriculum for } \\
\text { English demotivates KSA learners for learning } \\
\text { English. }\end{array}$ & & & & & \\
\hline 14 & $\begin{array}{l}\text { Lack of parents-teacher meeting at schools is one of } \\
\text { the barriers in learning English. }\end{array}$ & & & & & \\
\hline 15 & $\begin{array}{l}\text { Teachers' own lack of motivation in teaching English } \\
\text { at schools demotivate learners }\end{array}$ & & & & & \\
\hline 16 & $\begin{array}{l}\text { Lack of regular interaction between students and } \\
\text { teachers in English in school and college premises is } \\
\text { a barrier in learning English. }\end{array}$ & & & & & \\
\hline 17 & $\begin{array}{l}\text { Saudi students are too much possessed by the fear of } \\
\text { making mistakes. This prevents them from speaking } \\
\text { fearlessly }\end{array}$ & & & & & \\
\hline 18 & $\begin{array}{l}\text { Mismatch between school English curriculum and } \\
\text { tertiary English curriculum causes obstacle in } \\
\text { learning English }\end{array}$ & & & & & \\
\hline 19 & $\begin{array}{l}\text { Not introducing English in schools from elementary } \\
\text { grade (LKG/ UKG) onwards is also one of the } \\
\text { barriers in learning English. }\end{array}$ & & & & & \\
\hline
\end{tabular}




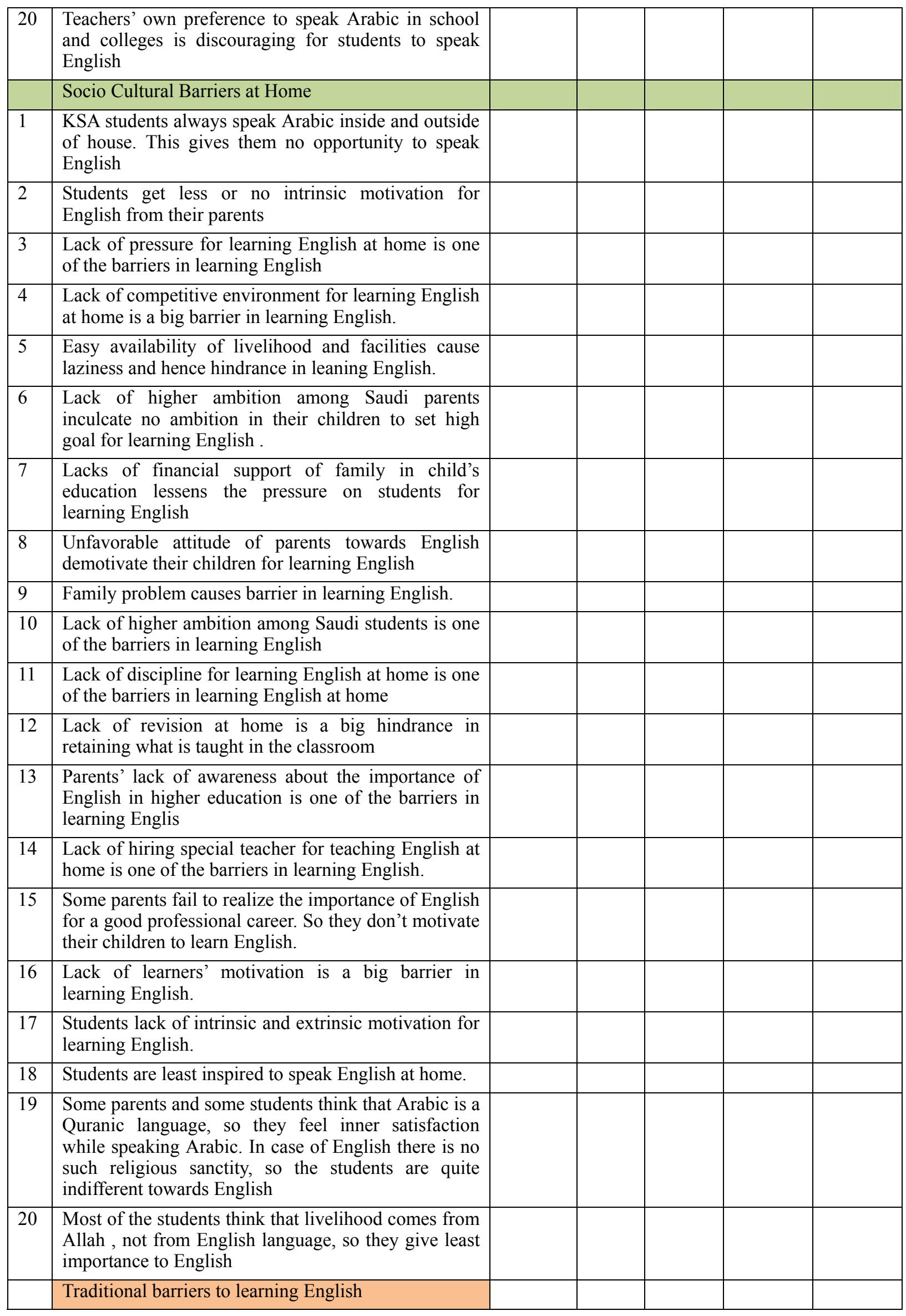




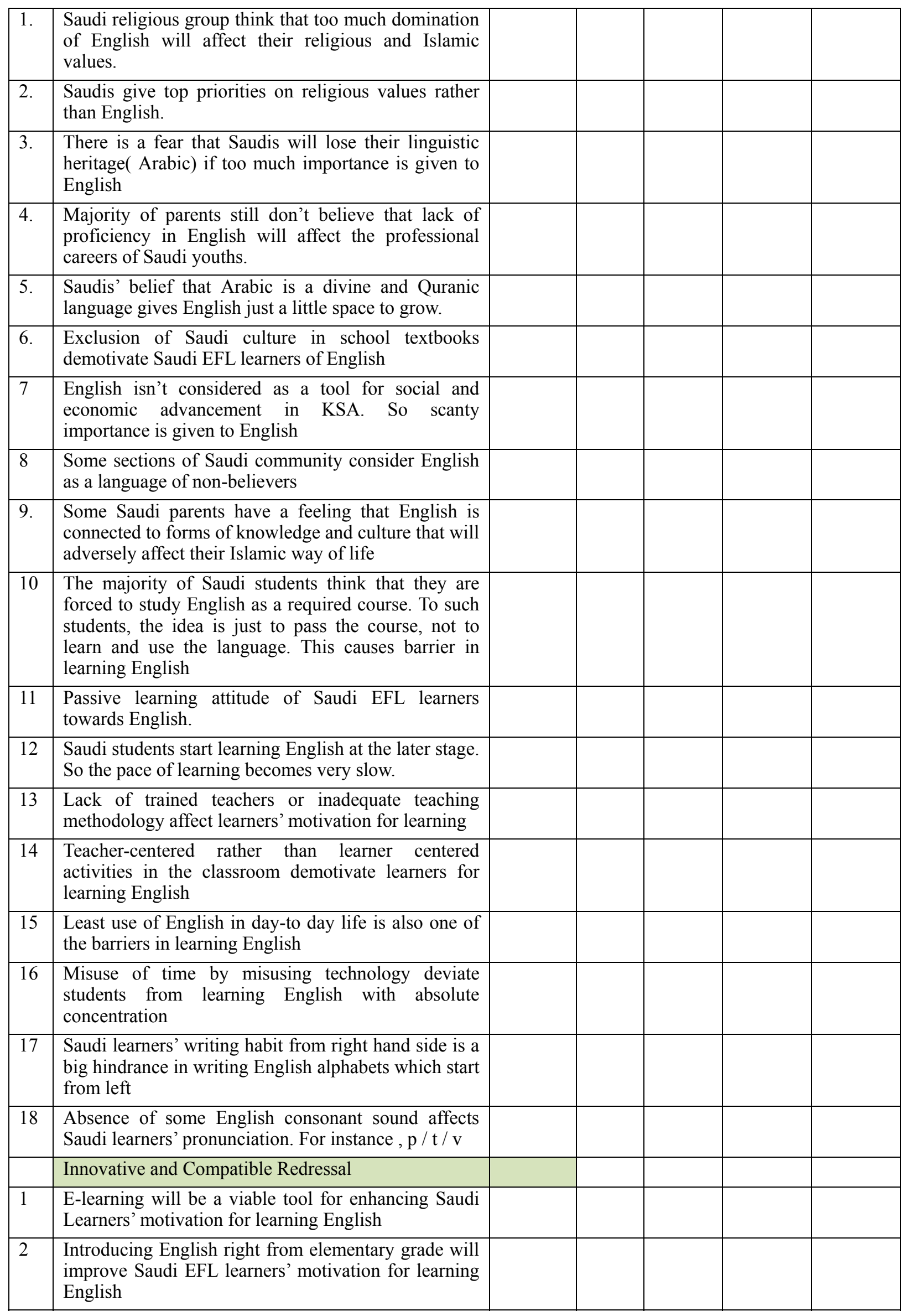




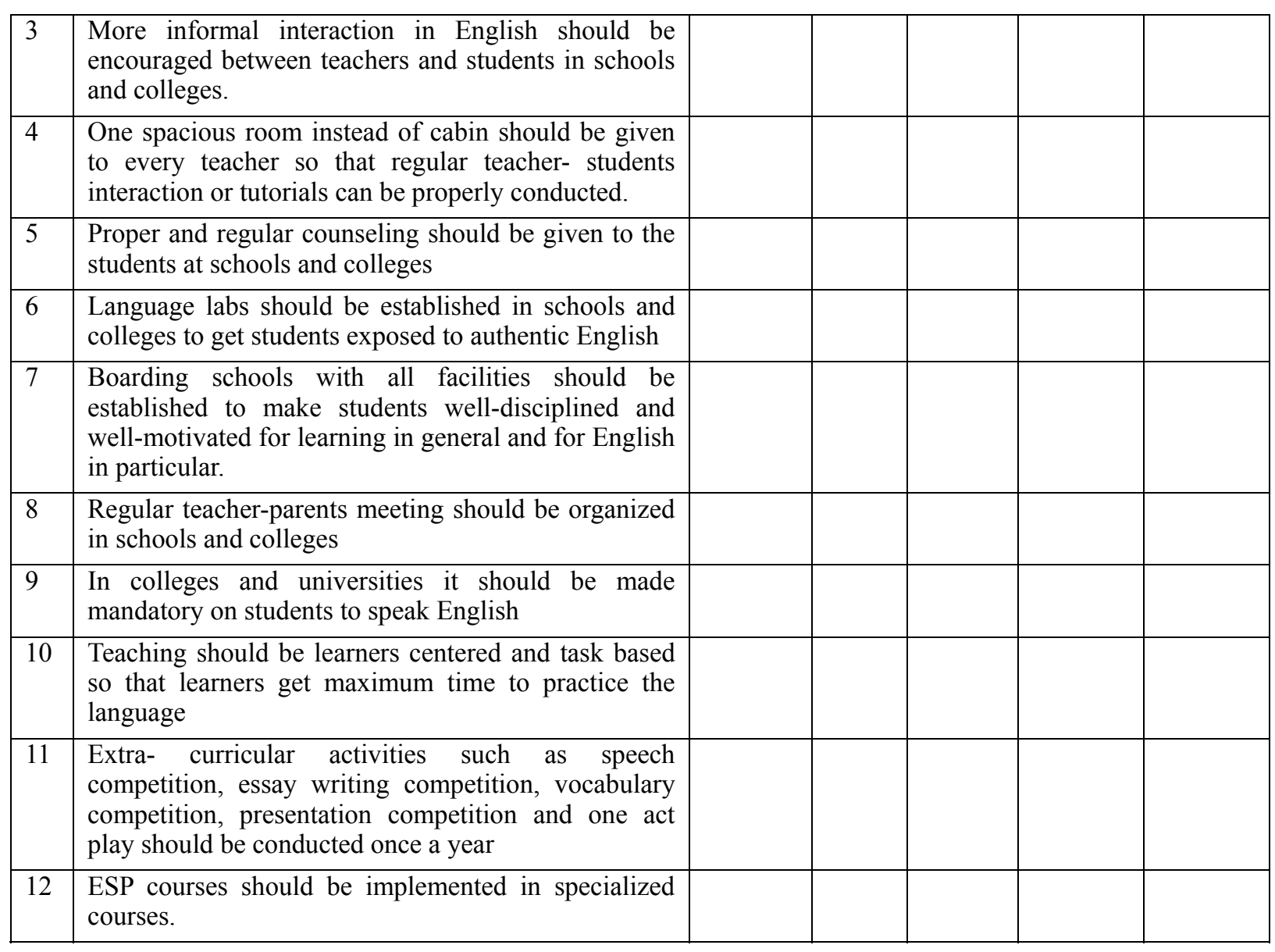

If you have any comments or suggestions pertaining to socio -cultural barriers in learning English in KSA and their viable redressal, please write them below.

This study, in addition to the above questionnaire, uses focus groups and individual interviews as other forms of data collection. In Focus Groups, a logical and argumentative discussion will be conducted among ELT teachers on 'Traditiuonal \& Socio-Cultural Barriers to EFL Learning.

\section{Anticipated time 30-75 minutes)}

In Individual interviews, face to face, through telephone or using the internet will be conducted - anticipated time 10-45 minutes)

If you would like to participate in the focus group and/or the individual interview, please provide your contact information below. (All personal information that could identify participants will be kept confidential.

Please note that the researcher will make every effort to accommodate as many participants as possible according to means and accessibility. 
Title of Research: Traditiuonal \& Socio-Cultural Barriers to EFL Learning: A Case Study

Name of Researcher: Dr. Jameel Ahmad

\begin{tabular}{|c|c|c|c|c|}
\hline $\begin{array}{c}\text { Do you study English at home every day? } \\
\text { هل دراسة اللغة الإنجليزية في المنزل كل يوم؟ }\end{array}$ & .1 & Yes & No & \\
\hline $\begin{array}{l}\text { Does your father motivate you to learn English at home? } \\
\text { هل تحفيز والدك للك لتعلم اللغة الانجليزية في المنزل؟ }\end{array}$ & .2 & Yes & No & \\
\hline $\begin{array}{l}\text { Do your parents help you to learn English at home? } \\
\text { هل يساعد والديك للك لتعلم اللغة الانجليزية في المنزل؟ }\end{array}$ & .3 & Yes & No & \\
\hline 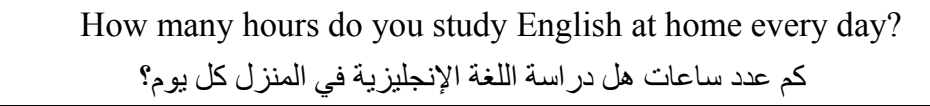 & .4 & $\begin{array}{l}1 \\
2\end{array}$ & 3 & 4 \\
\hline 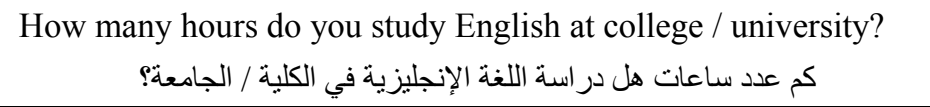 & .5 & $\begin{array}{l}1 \\
2\end{array}$ & 3 & 4 \\
\hline $\begin{array}{l}\text { Which grade was English introduced in your school? } \\
\text { التئي الصف والإنجليزية التي أدخلت فدرستك؟ }\end{array}$ & .6 & $4^{\text {th }}$ & $6^{\text {th }}$ & \\
\hline 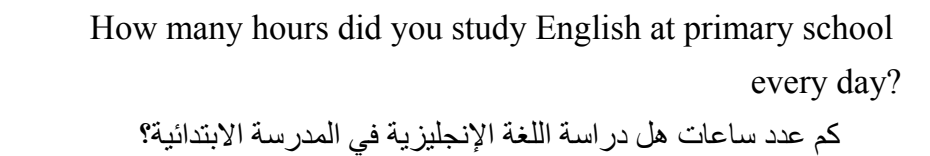 & .7 & $\begin{array}{l}1 \\
2\end{array}$ & 3 & 4 \\
\hline $\begin{array}{r}\text { How many hours did you study English at Secondary school } \\
\text { every day? }\end{array}$ & .8 & $\begin{array}{l}1 \\
2\end{array}$ & 3 & 4 \\
\hline $\begin{array}{r}\text { How many hours did you study English at senior Secondary } \\
\text { school every day? }\end{array}$ & .9 & $\begin{array}{l}1 \\
2\end{array}$ & & 4 \\
\hline
\end{tabular}

\section{Copyrights}

Copyright for this article is retained by the author(s), with first publication rights granted to the journal.

This is an open-access article distributed under the terms and conditions of the Creative Commons Attribution license (http://creativecommons.org/licenses/by/3.0/). 